\title{
Enterprise Strategy Radical Process and Charitable Donation: Taking A-share Manufacturing as an Example
}

\author{
Ruobing Deng ${ }^{\mathrm{a}}$, Yuan Su ${ }^{\mathrm{b}}$ \\ School of Economics and Management, Nanjing University of Science and Technology, \\ Xiaolingwei Street 200 , Nanjing, People's Republic of China

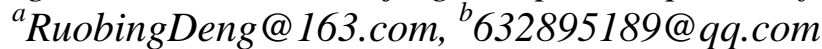

Keywords: business strategy; charitable donation; manufacturing

Abstract: Based on the data of listed companies in China's A-share manufacturing industry from 2008 to 2016, this paper empirically tests the relationship between corporate strategic aggressiveness and charitable donations. The results show that the more radical the company's strategy (exploration type), the more the company tends to make charitable donations, and the higher the level of charitable donations. The results show that corporate charitable donations are closely related to corporate strategy. This paper examines the motivations of charitable giving from the perspective of corporate strategy and helps to deepen our understanding of charitable donations.

\section{Introduction}

In recent years, China's philanthropy has developed rapidly. The participation of charitable donations in all walks of life has increased year by year. The target of charitable donations is no longer limited to public welfare donations after natural disasters, and gradually radiates to health care, environmental protection, education development and community building. . Compared with Western developed countries, personal donations are the main body. In China, enterprises are still the main donors.

Charitable donations are an important decision of the company and are closely related to the company's strategy. This article aims to examine the relationship between corporate strategy and charitable giving. Miles and Snow classifies corporate strategies based on the company's changing rate of change in its product market portfolio. There are generally three viable strategies in a particular industry: (1) "Explorer": frequent/rapid changes in product mix; (2) " Defenders: seldom/slowly changing product mix; (3) "Analyst": There are some common characteristics with explorers and defenders based on the use of technology, market, and management capabilities [1]. Bentley uses six indicators to identify the type of corporate strategy. Based on the classification method of Miles and Snow, this paper uses Bentley's indicator identification method to measure corporate strategy [2].

\section{Literature review and hypothesis development}

Companies that adopt an exploratory strategy are not able to understand the company's current 
situation, product sales, market conditions and development prospects because of the speed/frequency of its market portfolio. It leads to blind expansion and increases the company's operating risks. The company is in trouble. Therefore, companies implementing an exploratory strategy need to adopt risk aversion measures to reduce potential losses in the business process. Ramasamy and Yeung proposed that Chinese consumers pay more attention to socially responsible companies than European and American consumers when buying goods [3]. The Creyer and Rose surveys found that consumers are willing to pay a higher price to reward ethical companies and pay a lower price to punish unscrupulous companies [4]. Brown and Dacin found that corporate social responsibility behavior changes consumer perceptions of the business, and that social responsibility behavior acts as a property similar to another product in consumer purchasing decisions, thereby affecting consumer evaluation of the product [5]. Sen and Bhattacharya also confirmed that the level of corporate social responsibility has a significant impact on consumer product evaluation [6]. As a way for enterprises to actively fulfill their social responsibilities, charitable donation is conducive to shaping the good image of enterprises, accumulating moral capital for enterprises, increasing public recognition of the company, and reducing the future business risks of enterprises. Therefore, the management of the exploration company is more motivated to actively respond to the interests of the stakeholders through charitable donations.

Based on the above analysis, hypothesis 1 and hypothesis 2 are proposed:

$\mathrm{H} 1$ : When other conditions are the same, the more aggressive the corporate strategy, the more likely it is to make charitable donations.

H2: When other conditions are the same, the more aggressive the corporate strategy, the higher the level of charitable giving.

\section{Research design}

\subsection{Sample selection and data source}

Considering that there are large differences in the strategies of companies in different industries, it may have an impact on the conclusions of the study. The data used in this paper is from the CSMAR database and the National Bureau of Statistics.

\subsection{Research model setting}

In order to test the $\mathrm{H} 1$ and $\mathrm{H} 2$ proposed in the previous section, we set the regression equation to be tested as follows:

Donation $_{\mathrm{i}, \mathrm{t}}\left(\right.$ Duml_donation $\left._{\mathrm{i}, \mathrm{t}}\right)=\mathrm{a}_{0}+\mathrm{a}_{1}$ Strategy $_{\mathrm{i}, \mathrm{t}}+\mathrm{a}_{2} \mathrm{MP}_{\mathrm{t}}+\mathrm{a}_{3} \mathrm{SAi}, \mathrm{t}+\mathrm{a}_{4}$ Indep $_{\mathrm{i}, \mathrm{t}}+\mathrm{a}_{5}$ Part $_{\mathrm{i}, \mathrm{t}}+\mathrm{a}_{6}$ Ownersh $_{\mathrm{i}}$ ip $_{i, t}+a_{7}$ Insti $_{i, t}+a_{8}$ Soe $_{i, t}+a_{9} \operatorname{Lev}_{i, t}+a_{10}$ Roa $_{i, t}+a_{11}$ Age $_{i, t}+a_{12}$ Size $_{i, t}+a_{13} C_{\text {Cfo }}, t+E$

Among them, Donation ${ }_{i, t}$ and Duml_donation ${ }_{i, t}$ are the explanatory variables of Model 1, which represent the amount of charitable donations of company $\mathrm{i}$ in the t-year and whether the company $\mathrm{i}$ donates in the t-year. Donation ${ }_{i, t}$ the greater the value of $t$, the higher the company's donation amount, Duml_donation $_{i, t}$ when the value of 1 is 1 , the charity donation is carried out on behalf of the company $\mathrm{i}$ in the t-year. When the value is 0 , the company $\mathrm{i}$ has not made charitable donations in the t-year.

Strategy $y_{i, t}$ is the explanatory variable of Model 1, which represents the company's corporate strategy for the t-year.

The model also controls factors that may have an impact on corporate charitable giving. 


\section{Empirical analysis}

\subsection{Descriptive statistics}

Table 1 reports full sample descriptive statistics and group sample descriptive statistics for the primary variables. As can be seen from Table 1, it is preliminarily judged that companies following the exploratory strategy are more likely to conduct charity. Donate and the level of charitable donation of companies following the exploratory strategy is even higher.

Table 1 Descriptive Statistics

\begin{tabular}{|c|c|c|c|c|c|c|c|}
\hline \multirow{2}{*}{ Variable } & \multicolumn{4}{|c|}{ Full Sample(n=3608) } & \multirow{2}{*}{$\begin{array}{c}\text { Strategy } \geq 17 \\
\text { Mean }\end{array}$} & \multirow{2}{*}{$\begin{array}{c}\text { Strategy }<17 \\
\text { Mean } \\
\end{array}$} & \multirow{2}{*}{ T-test } \\
\hline & Min & Max & Mean & Std. Dev & & & \\
\hline Duml donation & 0.00 & 1.00 & 0.74 & 0.44 & 0.77 & 0.71 & 0.000 \\
\hline Donation & 0.00 & 8.64 & 4.26 & 2.64 & 4.51 & 4.05 & 0.000 \\
\hline Strategy & 6.00 & 29.00 & 17.02 & 4.38 & 20.94 & 13.73 & 0.003 \\
\hline MP & 0.00 & 1.00 & 0.80 & 0.40 & 0.80 & 0.80 & 0.722 \\
\hline SA & -4.20 & -3.08 & -3.68 & 0.18 & -3.67 & -3.68 & 0.080 \\
\hline Indep & 0.18 & 0.67 & 0.37 & 0.05 & 0.37 & 0.37 & 0.289 \\
\hline Part & 1.00 & 2.00 & 1.81 & 0.39 & 1.79 & 1.82 & 0.000 \\
\hline Ownership & 10.56 & 92.35 & 51.66 & 14.71 & 52.06 & 51.32 & 0.034 \\
\hline Insti & 0.00 & 72.67 & 6.94 & 10.31 & 7.91 & 6.12 & 0.007 \\
\hline Soe & 0.00 & 1.00 & 0.56 & 0.50 & 0.53 & 0.59 & 0.000 \\
\hline Lev & 0.02 & 12.13 & 0.49 & 0.34 & 0.48 & 0.50 & 0.107 \\
\hline Roa & -2.56 & 10.40 & 0.03 & 0.20 & 0.04 & 0.02 & 0.354 \\
\hline Age & 4.79 & 26.05 & 14.54 & 4.59 & 14.60 & 14.49 & 0.007 \\
\hline Size & 7.40 & 11.77 & 9.66 & 0.55 & 9.70 & 9.63 & 0.030 \\
\hline Cfo & -9.99 & 10.65 & 5.12 & 6.58 & 4.98 & 5.23 & 0.020 \\
\hline
\end{tabular}

\subsection{Regression analysis}

Based on the model established above, regression analysis was performed using the 2012-2016 panel data as a sample. Table 2 reports the relationship between corporate strategy and charitable giving in the full sample. The results show that the more aggressive the corporate strategy and the higher the level of charitable donations, the hypothesis 1 is verified. The coefficient of the strategy and whether it is a charitable donation (Duml_Donation) is 0.094, which is significant at the $1 \%$ level, indicating that the more aggressive the corporate strategy, the more likely it is to make charitable donations and verify the hypothesis 2 .

\section{Conclusion}

From the perspective of corporate strategy, this paper discusses the influencing factors of charitable donation by taking the sample of A-share manufacturing listed companies in China from 2008 to 2016 as a sample. The study found that the more radical the corporate strategy, the more likely corporate charity is to charitable donations, and the higher the level of charitable donations.

\section{References}

[1] Miles, R.E.,C.C.Snow.,A.D.Meyer. Organization Strategy, Structure, and Process [J]. Administrative Science Quarterly, 1978,3(3):546-562.

[2] Bentley, K.A.,T.C.Omer, and N.Y.Sharp. Business Strategy, Financial Reporting Irregularities, and Audit Effort [J]. 
Contemporary Accounting Research, 2013, 30(2):789-817.

[3] Ramasamy B,Yeung M. Chinese Consumers'Perception of Corporate Social

Responsibilty[J]. Journal of Business Ethics, 2009(88):119-132.

[4] Creyer E H,Ross W T. The Influence of Firm Behavior on Purchase Intention: Do Consumers Really Care about Business Ethics [J]. Journal of Consumer Marketing, 1997, 14: 421-432.

[5] Brown,T.J.and P.A.Dacin. The Company and the Product: Corporate Associations and Consumer Product Responses [J]. Journal of Marketing, 1997(61):68-84.

[6] Sen S,Bhattacharya C B. Does Doing Good Always Lead to Doing Better? Consumer Reactions to Corporate Social Responsibility [J]. Journal of Marketing Research, 2001(38): 225-243.

Table 2 Relationship test results of corporate strategy and charitable donation

\begin{tabular}{|c|c|c|c|c|}
\hline \multirow{2}{*}{ Variable } & \multicolumn{2}{|c|}{ Donation } & \multicolumn{2}{|c|}{ Duml_donation } \\
\hline & Coef & Sig. & Coef & Sig. \\
\hline Strategy & $0.110^{* * *}$ & 0.000 & $0.094^{* * *}$ & 0.000 \\
\hline MP & 0.002 & 0.908 & -0.010 & 0.536 \\
\hline SA & $-1.066 * * *$ & 0.000 & $-1.350 * * *$ & 0.000 \\
\hline Indep & -0.012 & 0.421 & -0.001 & 0.929 \\
\hline Part & $-0.045 * * *$ & 0.004 & $-0.046 * * *$ & 0.004 \\
\hline Ownership & $-0.078 * * *$ & 0.000 & $-0.074 * * *$ & 0.000 \\
\hline Insti & $-0.054 * * *$ & 0.001 & $-0.052 * * *$ & 0.001 \\
\hline Soe & $-0.157 * * *$ & 0.000 & $-0.129 * * *$ & 0.000 \\
\hline Lev & 0.002 & 0.886 & 0.022 & 0.173 \\
\hline Roa & $0.034 * *$ & 0.025 & $0.027 *$ & 0.093 \\
\hline Age & $-1.130 * * *$ & 0.000 & $-1.416^{* * *}$ & 0.000 \\
\hline Size & $0.683 * * *$ & 0.000 & $0.666 * * *$ & 0.000 \\
\hline Cfo & $0.079 * * *$ & 0.000 & $0.072 * * *$ & 0.000 \\
\hline Year & \multicolumn{2}{|c|}{ Control } & \multicolumn{2}{|c|}{ Control } \\
\hline Observations & \multicolumn{2}{|c|}{3608} & \multicolumn{2}{|c|}{3608} \\
\hline Adjust R2 & \multicolumn{2}{|c|}{$18.00 \%$} & \multicolumn{2}{|c|}{$12.20 \%$} \\
\hline F-value & \multicolumn{2}{|c|}{61.924} & \multicolumn{2}{|c|}{39.44} \\
\hline
\end{tabular}

